\title{
KONTRIBUSI SEKTOR PERTANIAN TERHADAP PEMBANGUNAN EKONOMI KABUPATEN POSO
}

\author{
Marianne Reynelda Mamondol \\ Fakultas Pertanian Universitas Kristen Tentena \\ E-mail : mariannemamondol@ymail.com
}

\begin{abstract}
ABSTRAK
Penelitian ini bertujuan untuk: (a) mengetahui kontribusi sektor pertanian terhadap pembangunan ekonomi Kabupaten Poso, dan (b) menentukan apakah sektor pertanian merupakan sektor basis atau non basis yang menggerakkan pembangunan ekonomi Kabupaten Poso. Metode survey digunakan untuk mengumpulkan data melalui studi dokumentasi terhadap PDRB Kabupaten Poso dan Provinsi Sulawesi Tengah dari tahun 2009 hingga 2013. Data dianalisis dengan menggunakan analisis kontribusi dan analisis basis ekonomi. Hasil penelitian menunjukkan bahwa sektor pertanian berkontribusi rata-rata sebesar 44,07 \% selama tahun 2009 hingga 2013. Pertanian merupakan sektor basis dengan nilai LQ lebih besar daripada 1. Sub sektor yang merupakan sektor basis ialah tanaman bahan makanan, tanaman perkebunan, dan kehutanan, sedangkan peternakan dan perikanan merupakan sub sektor non basis. Hasil analisis lokalisasi menunjukkan bahwa aktivitas sektor pertanian dan semua sub sektornya belum terkonsentrasi pada wilayah-wilayah tertentu. Analisis spesialisasi juga menunjukkan bahwa belum terdapat spesialisasi produksi komoditas tertentu pada sektor pertanian Kabupaten Poso. Walaupun demikian, hasil analisis BSR dan REM memperlihatkan bahwa sektor pertanian, khususnya subsub sektor basisnya berperan penting dalam ekonomi regional sebagai sumber pendapatan dan lapangan kerja bagi masyarakat. Peningkatan sektor basis sebesar $1 \%$ dapat meningkatkan produktivitas sektor non basis lebih besar daripada $1 \%$. Hal ini memungkinkan sektor non basis untuk berkontribusi terhadap pertumbuhan ekonomi regional.
\end{abstract}

Kata kunci : Kontribusi, sektor basis, sektor non basis

\begin{abstract}
The purposes of this research are : (a) to find out the contribution of agriculture sector on Poso Regency economic development, and (b) to determine whether agriculture sector belongs to basic or non basic sector which triggering Poso Regency economic development. Survey method is applied to collect data through the documentation of GRDP of Poso Regency and Central Sulawesi Province for the Year of 2009 to 2013. Data is analyzed using analyses of contribution and economic base. Result demonstrates that agriculture sector contributes averagely $44.07 \%$ throughout the year of 2009 to 2013. Agriculture belongs to basic sector with LQ value as many as more than 1. Sub sectors that belong to basic sub sector are food crop, plantation crop, and forestry, whereas livestock and fisheries belong to non basic sector. The result of localization analysis shows that the activities of agriculture sector and all its sub sectors have not yet been concentrated in certain areas. Specialization analysis also exhibits that there has not yet a production specialization on certain commodities at agriculture sector in Poso Regency. Nevertheless, the results of BSR and REM analyses demonstrate that agriculture sector, particularly its basic sub sectors have important roles in regional economic as either the source of
\end{abstract}


income or field of work for society. The increasing of basic sector as high as $1 \%$ can enhance the productivity of non basic sector more than $1 \%$. This allows non basic sector to make a contribution to the growth of regional economic.

Keywords : Contribution, basic sector, non basic sector

\section{PENDAHULUAN}

Pembangunan pertanian pada fase desentralisasi ekonomi saat ini berpotensi menjadi basis kemandirian ekonomi bagi daerah, termasuk Kabupaten Poso. Sebagai suatu modal dasar, sektor pertanian dapat menciptakan dampak ganda (multiplier) bagi aktivitas ekonomi daerah. Daerah otonom dituntut mampu menjadi motivator dan fasilitator pemanfaatan sumberdaya yang dimiliki dalam rangka pembangunan daerah. Penetapan kawasan andalan sebagai sektor basis daerah yang selanjutnya menjadi titik-titik pertumbuhan perekonomian daerah merupakan salah satu upaya peningkatan pembangunan ekonomi. Upaya ini diharapkan akan mendorong tumbuh dan berkembangnya daerah sebagai pusat pertumbuhan perekonomian sehingga pada akhirnya daerah akan menjadi tulang punggung perekonomian nasional.

Teori basis ekspor (export base theory) membagi wilayah yang melakukan kegiatan perdagangan menjadi dua, yaitu wilayah yang bersangkutan dan wilayah-wilayah sisanya. Demikian pula struktur perekonomian dibedakan menjadi dua, yaitu sektor dasar atau sektor basis (basic activities) dan sektor non dasar atau sektor non basis (non basic activities). Sektor basis merupakan sektor di mana terdapat kegiatan-kegiatan yang menghasilkan barang-barang yang akan diekspor ke luar wilayah, sedangkan sektor non basis merupakan sektor di mana terdapat kegiatankegiatan produksi barang dan jasa untuk memenuhi kebutuhan masyarakat di wilayah yang bersangkutan. Asumsi yang digunakan ialah bahwa sektor basis merupakan kunci pertumbuhan wilayah (Adisasmita, 2008).

Teori Location Quotient (LQ) digunakan untuk menganalisis dan menentukan keragaman basis ekspor. Pendekatan yang digunakan berupa identifikasi sektor potensial yang dapat menjadi penggerak pertumbuhan dan perkembangan wilayah. Berdasarkan analisis tersebut dapat diidentifikasi sektor apa saja yang dapat dikembangkan untuk tujuan ekspor dan tujuan pemenuhan kebutuhan lokal, sehingga sektor yang dikatakan potensial dapat dijadikan prioritas utama dalam perencanaan pembangunan perekonomian (Syafruddin et al, 2004).

Menurut Azis (1994), LQ merupakan suatu indikator sederhana yang menunjukkan "kekuatan" atau besar-kecilnya peranan suatu sektor dalam suatu daerah dibandingkan dengan peranan sektor yang sama pada daerah lain. Pada dasarnya teknik ini menyajikan perbandingan relatif antara kemampuan suatu sektor di daerah yang diselidiki dengan kemampuan sektor yang sama pada daerah yang lebih luas. Hasil perbandingan ini dibandingkan kembali dengan total PDRB wilayah penelitian (misalnya kabupaten/kota) dan total PDRB yang lebih besar (provinsi). Analisis LQ merupakan salah satu ukuran statistik yang dapat digunakan sebagai bahan perencanaan ekonomi. Teknik ini dapat membantu dalam menentukan kapasitas ekspor perekonomian daerah.

Berdasarkan analisis LQ tersebut, dapat ditentukan status basis dan non basis dari sektorsektor ekonomi yang ada, yaitu sektor basis bila nilai LQ > 1 dan sektor non basis bila nilai $\mathrm{LQ}<1$. Data-data tersebut sangat dibutuhkan untuk analisis lebih lanjut tentang perkembangan dan multiplier effect dari perkembangan masing-masing sektor.

Menurut Tarigan (2005), kegiatan ekonomi regional terdiri dari kegiatan basis dan non basis. Dengan demikian kegiatan basis ditambah dengan kegiatan non basis sama dengan seluruh kegiatan ekonomi untuk suatu daerah. Rasio kegiatan basis dan non basis dinamakan rasio dasar ekonomi atau multiplier dasar. Multiplier dasar diartikan sebagai jumlah dua komponen dari rasio dasar di mana komponen tersebut adalah kegiatan basis dan non basis. Multiplier dasar adalah suatu 
estimasi dari total perubahan yang dihasilkan dari suatu perubahan sektor basis dalam menanggapi permintaan untuk ekspor dan akan melipatgandakan kegiatan baru dalam kegiatan non basis.

Berdasarkan uraian tersebut maka rumusan masalah dalam penelitian ini ialah : (a) Berapakah kontribusi sektor pertanian terhadap pembangunan ekonomi Kabupaten Poso, dan (b) Apakah sektor pertanian merupakan sektor basis atau non basis yang dapat menggerakkan pembangunan ekonomi Kabupaten Poso ? Tujuan penelitian ini ialah untuk : (a) Mengetahui kontribusi sektor pertanian terhadap pembangunan ekonomi Kabupaten Poso, dan (b) Menentukan sektor pertanian sebagai sektor basis atau non basis yang dapat menggerakkan pembangunan ekonomi Kabupaten Poso.

\section{METODE PENELITIAN}

Penelitian ini dilaksanakan pada bulan April 2014 hingga Mei 2014 di Kabupaten Poso Provinsi Sulawesi Tengah. Metode pengumpulan data yang digunakan ialah metode survey dengan cara dokumentasi, yaitu pemeriksaan dan pengumpulan dokumen-dokumen yang berhubungan dengan kepentingan penelitian.

Jenis data yang dikumpulkan ialah data sekunder berupa data Produk Domestik Regional Bruto (PDRB) Kabupaten Poso dan Provinsi Sulawesi Tengah tahun 2009 sampai dengan tahun 2013. Sumber data ialah instansi pemerintah, dalam hal ini Badan Pusat Statistik (BPS) Kabupaten Poso dan Provinsi Sulawesi Tengah. Data diakses secara online dari website resmi kedua instansi tersebut.

Teknik analisis data yang digunakan dalam penelitian ini meliputi :

\section{Analisis Kontribusi}

Analisis kontribusi (Share Analysis) yaitu analisis yang digunakan untuk mengetahui besarnya kontribusi suatu sektor terhadap PDRB suatu daerah. Menurut Tarigan (2005), besarnya kontribusi dapat dihitung dengan rumus :

Share $=\frac{\text { PDRB Sektor atau Subsektor }}{\text { PDRB Total }} \times 100 \%$

\section{Analisis Basis Ekonomi} berikut :

Menurut Glasson (1997), analisis basis ekonomi meliputi beberapa komponen sebagai

a. Analisis Location Quotient (LQ), yaitu analisis yang digunakan untuk menentukan basis atau tidaknya kegiatan ekonomi suatu daerah. Kriteria yang digunakan ialah bahwa jika nilai LQ > 1 berarti sektor usaha tersebut merupakan sektor basis yang dapat dikategorikan sebagai sektor unggulan. Rumus analisis Location Quotient (LQ) ialah sebagai berikut :

$$
L Q=\frac{x_{i}}{x} / \frac{x_{i}}{X}
$$

Keterangan :

LQ = Nilai koefisien aktivitas ekonomi Kabupaten Poso

$\mathrm{x}_{\mathrm{i}} \quad=$ Nilai PDRB masing-masing sektor usaha Kabupaten Poso

$\mathrm{x}=$ Nilai PDRB total seluruh sektor usaha di Kabupaten Poso

$\mathrm{X}_{\mathrm{i}} \quad=$ Nilai PDRB masing-masing sektor usaha di Provinsi Sulawesi Tengah

$\mathrm{X}=$ Nilai PDRB total seluruh sektor usaha di Provinsi Sulawesi Tengah 
b. Analisis Koefisien Lokalisasi $(\alpha)$, yaitu analisis yang memberikan gambaran apakah suatu sektor ekonomi atau aktivitas ekonomi terlokalisasi (terkonsentrasi) pada suatu wilayah tertentu atau menyebar ke beberapa wilayah. Rumus analisis Koefisien Lokalisasi $(\alpha)$ ialah sebagai berikut :

$$
\alpha_{i}=x_{i} / X_{i}-x / x
$$

Keterangan :

$\alpha_{\mathrm{i}} \quad=$ Nilai derajat konsentrasi masing-masing sektor usaha di Kabupaten Poso

$\mathrm{x}_{\mathrm{i}} \quad=$ Nilai PDRB masing-masing sektor usaha Kabupaten Poso

$\mathrm{x}=$ Nilai PDRB total seluruh sektor usaha di Kabupaten Poso

$\mathrm{X}_{\mathrm{i}} \quad=$ Nilai PDRB masing-masing sektor usaha di Provinsi Sulawesi Tengah

$\mathrm{X}=$ Nilai PDRB total seluruh sektor usaha di Provinsi Sulawesi Tengah

Apabila nilai $\alpha_{\mathrm{i}} \geq 1$ berarti jenis aktivitas yang dianalisis terlokalisasi (terkonsentrasi) dalam pembangunan perekonomian wilayah setempat, sedangkan jika nilai $\alpha_{i}<1$ berarti jenis aktivitas ekonomi tidak terkonsentrasi dalam pembangunan wilayah setempat.

c. Analisis Koefisien Spesialisasi $\left(\beta_{\mathrm{i}}\right)$, yaitu analisis yang menunjukkan apakah suatu wilayah mengkhususkan diri terhadap suatu jenis komoditi tertentu atau tidak ada pengkhususan (spesialisasi). Rumus analisis Koefisien Spesialisasi ialah sebagai berikut :

$$
\beta_{i}=x_{i} / X_{i}-x / x
$$

Keterangan :

$\beta_{\mathrm{i}}=$ Nilai koefisien spesialisasi masing-masing sektor usaha di Kabupaten Poso

$\mathrm{x}_{\mathrm{i}} \quad=$ Nilai PDRB masing-masing sektor usaha Kabupaten Poso

$\mathrm{x}=$ Nilai PDRB total seluruh sektor usaha di Kabupaten Poso

$\mathrm{X}_{\mathrm{i}} \quad=$ Nilai PDRB masing-masing sektor usaha di Provinsi Sulawesi Tengah

$\mathrm{X}=$ Nilai PDRB total seluruh sektor usaha di Provinsi Sulawesi Tengah

Apabila nilai $\beta_{i} \geq 1$ berarti suatu sektor usaha mengkhususkan diri atau memiliki spesialisasi dalam pembangunan perekonomian di wilayah tersebut, sedangkan apabila nilai $\beta_{\mathrm{i}}<1$ berarti tidak terjadi spesialisasi secara sektoral dalam pembangunan perekonomian wilayah yang dianalisis.

d. Analisis Basic Service Ratio (BSR), yaitu analisis yang digunakan untuk mengetahui sejauh mana hubungan dan pengaruh antar sektor basis (leading sector) dengan sektor non basis (penunjang) pada suatu wilayah. Nilai BSR diperoleh dengan menggunakan rumus sebagai berikut :

$\mathrm{BSR}=\frac{\sum \mathrm{B}}{\sum \mathrm{NB}}$ atau $\mathrm{BSR}=\frac{\sum \Delta \mathrm{B}}{\sum \Delta \mathrm{NB}}$

Keterangan :

$\sum \mathrm{B}=$ Jumlah nilai sektor basis

$\sum \mathrm{NB}=$ Jumlah nilai sektor non basis

$\sum \Delta \mathrm{B}=$ Tambahan (perubahan) nilai sektor basis

$\sum \Delta \mathrm{NB}=$ Tambahan (perubahan) nilai sektor non basis

Apabila nilai BSR semakin positif berarti sektor basis di daerah tersebut memberikan kontribusi yang positif terhadap perkembangan sektor non basis. Dengan kata lain, jika nilai 
BSR sebesar 1 satuan, maka peningkatan sektor basis ialah juga sebesar 1 satuan. Hal ini berarti sektor basis mempunyai hubungan yang positif terhadap pertumbuhan sektor non basis di daerah tersebut.

e. Analisis Regional Employment Multiplier (Basis Multiplier), yaitu analisis yang merupakan tindak lanjut dari analisis BSR yang menekankan pada sejumlah mana pertumbuhan dan atau perkembangan sektor basis memberikan pengaruh terhadap perkembangan dan atau pertumbuhan sektor non basis pada setiap kenaikan 1 satuan dari sektor non basis. Nilai REM diperoleh dengan menggunakan rumus sebagai berikut :

$\mathrm{REM}=1+\frac{1}{\mathrm{BSR}}$

\section{HASIL DAN PEMBAHASAN}

\section{Analisis Kontribusi}

Tabel 1. Data PDRB Kabupaten Poso Tahun 2009 - 2013 Lapangan Usaha Pertanian Atas Dasar Harga Konstan 2000

(Table 1. GRDP of Poso Regency at The Year of 2009 to 2013 for Agriculture Industrial Origin Based On Constant 2000 Market Price)

\begin{tabular}{|c|c|c|c|c|c|}
\hline \multirow{2}{*}{ Lapangan Usaha } & \multicolumn{5}{|c|}{ PDRB (juta rupiah) } \\
\hline & 2009 & 2010 & 2011 & 2012 & 2013 \\
\hline Pertanian & 457.532 & 496.058 & 537.086 & 579.826 & 625.284 \\
\hline $\begin{array}{l}\text { a. Tanaman } \\
\text { bahan makanan }\end{array}$ & 132.070 & 147020 & 164.839 & 182840 & 201.103 \\
\hline $\begin{array}{l}\text { b. Tanaman } \\
\text { perkebunan } \\
\text { c. Peternakan dan }\end{array}$ & 203.628 & 220.630 & 238.206 & 256.150 & 275.611 \\
\hline hasil-hasilnya & 14.757 & 15.314 & 16.277 & 17.610 & 18.844 \\
\hline d. Kehutanan & 56.058 & 59.113 & 60.539 & 62.785 & 65.785 \\
\hline e. Perikanan & 51.018 & 53.981 & 57.225 & 60.440 & 63.941 \\
\hline PDRB Total & 1.028 .969 & 1.110 .919 & 1.201 .653 & 1.301 .575 & 1.411 .369 \\
\hline
\end{tabular}

Sumber : BPS Poso, 2014

Berdasarkan data pada Tabel 1 dapat dihitung kontribusi sektor pertanian dan sub-sub sektornya terhadap PDRB Kabupaten Poso, sebagaimana yang ditunjukkan pada Tabel 2 sebagai berikut.

Tabel 2. Kontribusi Sektor Pertanian Terhadap PDRB Kabupaten Poso Tahun 2009 - 2013

(Table 2. The Contribution of Agriculture Sector on GRDP of Poso Regency Year 2009-2013)

\begin{tabular}{|c|c|c|c|c|c|c|}
\hline \multirow[t]{2}{*}{ Lapangan Usaha } & \multicolumn{5}{|c|}{ Kontribusi (\%) } & \multirow[t]{2}{*}{ Rata-rata } \\
\hline & 2009 & 2010 & 2011 & 2012 & 2013 & \\
\hline Pertanian & 44,57 & 42,22 & 44,70 & 44,55 & 44,30 & 44,07 \\
\hline a. Tanaman bahan makanan & 12,84 & 13,23 & 13,72 & 14,05 & 14,25 & 13,62 \\
\hline b. Tanaman perkebunan & 19,79 & 19,86 & 19,82 & 19,68 & 19,53 & 19,74 \\
\hline $\begin{array}{l}\text { c. Peternakan dan hasil- } \\
\text { hasilnya }\end{array}$ & 1,43 & 1,38 & 1,35 & 1,35 & 1,34 & 1,37 \\
\hline d. Kehutanan & 5,45 & 5,32 & 5,04 & 4,82 & 4,66 & 5,06 \\
\hline e. Perikanan & 4,96 & 4,86 & 4,76 & 4,64 & 4,53 & 4,75 \\
\hline
\end{tabular}


Tabel 2 memperlihatkan bahwa sektor pertanian memiliki kontribusi antara 42,22\% hingga 44,70 \% terhadap PDRB Kabupaten Poso sepanjang tahun 2009 hingga 2013, atau rata-rata sebesar 44,07\% per tahun. Angka-angka tersebut mengindikasikan bahwa hingga tahun 2013 sektor pertanian masih menjadi tumpuan perekonomian daerah. Akan tetapi terjadi kecenderungan penurunan kontribusi sejak tahun 2011 yang diakibatkan adanya peningkatan kontribusi dari sektor lain di luar pertanian.

Ditinjau dari setiap sub sektor terlihat bahwa sub sektor tanaman perkebunan memberikan kontribusi terbesar yang berkisar antara 19,53\% hingga 19,86\% atau rata-rata sebesar 19,74\% per tahun. Kontribusi tersebut umumnya berasal dari tanaman kakao yang merupakan komoditas unggulan Kabupaten Poso. Akan tetapi kontribusi sub sektor perkebunan bersama-sama dengan sub sektor peternakan, kehutanan, dan perikanan terus menunjukkan adanya penurunan dari tahun ke tahun. Satu-satunya sub sektor yang memperlihatkan kenaikan kontribusi ialah sub sektor tanaman bahan makanan dengan padi dan jagung sebagai komoditas utamanya. Peningkatan produksi merupakan faktor yang berperan menunjang peningkatan kontribusi tersebut.

\section{Analisis Basis Ekonomi}

Tabel 3. Data PDRB Provinsi Sulawesi Tengah Tahun 2009 - 2013 Lapangan Usaha Pertanian Atas Dasar Harga Konstan 2000

(Table 3. GRDP of Central Sulawesi Province at The Year of 2009 to 2013 for Agriculture Industrial Origin Based On Constant 2000 Market Price)

\begin{tabular}{|c|c|c|c|c|c|}
\hline \multirow[t]{2}{*}{ Lapangan Usaha } & \multicolumn{5}{|c|}{ PDRB (juta rupiah) } \\
\hline & 2009 & 2010 & 2011 & 2012 & 2013 \\
\hline Pertanian & 6.652 .547 & 7.051 .387 & 7.542 .543 & 7.979 .414 & 8.423 .688 \\
\hline $\begin{array}{l}\text { a. Tanaman } \\
\text { bahan makanan }\end{array}$ & 2.105 .500 & 2.186 .830 & 2.186 .830 & 2.390 .290 & 2.475 .209 \\
\hline $\begin{array}{l}\text { b. Tanaman } \\
\text { perkebunan } \\
\text { c. Peternakan dan }\end{array}$ & 2.506 .064 & 2.693 .643 & 2.896 .870 & 3.086 .092 & 3.284 .229 \\
\hline hasil-hasilnya & 385.780 & 409.976 & 439.781 & 465.823 & 497.933 \\
\hline d. Kehutanan & 642.007 & 670.944 & 712.243 & 766.288 & 774.136 \\
\hline e. Perikanan & 1.013 .196 & 1.089 .994 & 1.178 .621 & 1.270 .922 & 1.392 .182 \\
\hline PDRB Total & 16.207 .596 & 17.624 .174 & 19.230 .919 & 21.007 .973 & 22.979 .182 \\
\hline
\end{tabular}

Sumber : BPS Sulteng, 2014

Berdasarkan data pada Tabel 1 dan Tabel 3 dapat dihitung nilai LQ sebagaimana yang ditunjukkan pada Tabel 4 sebagai berikut.

Tabel 4. Nilai LQ Sektor Pertanian di Kabupaten Poso Tahun 2009 - 2013

(Table 4. LQ Value of Agriculture Sector in Poso Regency Year 2009-2013)

\begin{tabular}{|c|c|c|c|c|c|}
\hline \multirow[t]{2}{*}{ Lapangan Usaha } & \multicolumn{5}{|c|}{ LQ } \\
\hline & 2009 & 2010 & 2011 & 2012 & 2013 \\
\hline Pertanian & 1,085 & 1,118 & 1,140 & 1,171 & 1,207 \\
\hline $\begin{array}{l}\text { a. Tanaman bahan } \\
\text { makanan }\end{array}$ & 0,984 & 1,065 & 1,202 & 1,228 & 1,315 \\
\hline $\begin{array}{l}\text { b. Tanaman } \\
\text { perkebunan }\end{array}$ & 1,277 & 1,301 & 1,311 & 1,340 & 1,364 \\
\hline $\begin{array}{l}\text { c. Peternakan dan } \\
\text { hasil-hasilnya }\end{array}$ & 0,583 & 0,609 & 0,609 & 0,636 & 0,591 \\
\hline d. Kehutanan & 1,350 & 1,395 & 1,351 & 1,333 & 1,382 \\
\hline e. Perikanan & 0,794 & 0,790 & 0,787 & 0,767 & 0,738 \\
\hline
\end{tabular}


Sektor pertanian secara keseluruhan merupakan sektor basis bagi Kabupaten Poso, yang ditunjukkan dengan nilai LQ > 1. Sub sektor basis meliputi sub sektor tanaman bahan makanan, tanaman perkebunan, dan kehutanan, sedangkan sub sektor peternakan dan perikanan merupakan sub sektor non basis. Beberapa komoditas seperti padi, jagung, kakao, dan rotan telah disuplai keluar daerah untuk memenuhi kebutuhan konsumen maupun industri yang ada di luar wilayah Kabupaten Poso. Sub sektor peternakan dan perikanan yang termasuk sektor non basis merupakan sektor yang kegiatan produksinya terbatas hanya untuk pemenuhan kebutuhan lokal, bahkan diperlukan adanya pasokan dari luar daerah untuk memenuhi kebutuhan konsumen lokal. Hal ini sepatutnya mendapat perhatian dari pemerintah daerah mengingat ketersediaan sumberdaya alam yang sebenarnya sangat memadai untuk dilakukannya pengembangan potensi peternakan dan perikanan. Peningkatan produksi dapat mengurangi ketergantungan pasokan dari luar wilayah serta menjamin ketersediaan produk ternak dan ikan sebagai sumber protein yang sangat dibutuhkan bagi tercukupinya kebutuhan gizi masyarakat.

Hasil perhitungan nilai koefisien lokalisasi dapat dilihat pada Tabel 5 sebagai berikut.

Tabel 5. Koefisien Lokalisasi Sektor Pertanian di Kabupaten Poso Tahun 2009 - 2013

(Table 5. Localization Coefficient of Agriculture Sector in Poso Regency Year 2009-2013)

\begin{tabular}{|c|c|c|c|c|c|}
\hline \multirow[t]{2}{*}{ Lapangan Usaha } & \multicolumn{5}{|c|}{ Koefisien Lokalisasi } \\
\hline & 2009 & 2010 & 2011 & 2012 & 2013 \\
\hline Pertanian & 0,006 & 0,007 & 0,009 & 0,011 & 0,013 \\
\hline $\begin{array}{l}\text { a. Tanaman bahan } \\
\text { makanan }\end{array}$ & $-0,003$ & 0,004 & 0,013 & 0,014 & 0,020 \\
\hline $\begin{array}{l}\text { b. Tanaman } \\
\text { perkebunan }\end{array}$ & 0,018 & 0,019 & 0,020 & 0,021 & 0,023 \\
\hline $\begin{array}{l}\text { c. Peternakan dan } \\
\text { hasil-hasilnya }\end{array}$ & $-0,025$ & $-0,026$ & $-0,025$ & $-0,024$ & $-0,023$ \\
\hline d. Kehutanan & 0,024 & 0,025 & 0,023 & 0,020 & 0,024 \\
\hline e. Perikanan & $-0,013$ & $-0,013$ & $-0,013$ & $-0,014$ & $-0,015$ \\
\hline
\end{tabular}

Analisis koefisien lokalisasi $(\alpha)$ digunakan untuk memberikan gambaran apakah suatu sektor ekonomi terkonsentrasi pada suatu wilayah tertentu atau menyebar ke beberapa wilayah. Apabila nilai koefisien $\alpha$ lebih besar atau sama dengan 1 maka dapat dikatakan bahwa jenis aktivitas ekonomi yang dianalisis terkonsentrasi dalam pembangunan perekonomian wilayah setempat.

Hasil analisis koefisien $\alpha$ menunjukkan bahwa sektor pertanian dan semua sub sektornya yang berada di Kabupaten Poso tidak terkonsentrasi pada suatu wilayah tertentu, melainkan menyebar pada beberapa wilayah. Hal ini tampak dari nilai $\alpha$ yang lebih kecil daripada 1 pada sektor pertanian dan masing-masing sub-sub sektornya.

Hasil analisis dengan pendekatan nilai LQ memperlihatkan bahwa beberapa sub sektor pertanian Kabupaten Poso memiliki karakteristik ekspor yang ditandai dengan adanya beberapa sub sektor basis. Akan tetapi hasil analisis koefisien $\alpha$ menunjukkan bahwa sub-sub sektor basis tersebut tidak terkonsentrasi dalam pengembangan pembangunan wilayah. Apabila kedua hasil analisis tersebut dihubungkan maka dapat disimpulkan bahwa sub-sub sektor basis sesungguhnya hanya mampu memenuhi kebutuhan wilayah Kabupaten Poso dan belum mampu diarahkan untuk melakukan ekspor ke luar wilayah.

Karena itu merupakan tugas pemerintah daerah untuk mengkonsentrasikan aktivitas sektor pertanian dalam pembangunan, terutama sub-sub sektor basis yang memiliki peluang ekspor. Konsentrasi harus dilakukan agar terjadi pemusatan produksi yang memiliki keunggulan sehingga mampu menghasilkan surplus yang dapat memenuhi kebutuhan wilayah dan ekspor.

Hasil perhitungan nilai koefisien spesialisasi dilihat pada Tabel 6 sebagai berikut. 
Tabel 6. Koefisien Spesialisasi Sektor Pertanian di Kabupaten Poso Tahun 2009 - 2013

(Table 6. Specialization Coefficient of Agriculture Sector in Poso Regency Year 2009 - 2013)

\begin{tabular}{|c|c|c|c|c|c|}
\hline \multirow[t]{2}{*}{ Lapangan Usaha } & \multicolumn{5}{|c|}{ Koefisien Spesialisasi } \\
\hline & 2009 & 2010 & 2011 & 2012 & 2013 \\
\hline Pertanian & 0,035 & 0,047 & 0,055 & 0,065 & 0,076 \\
\hline $\begin{array}{l}\text { Tanaman bahan } \\
\text { makanan }\end{array}$ & 0,002 & 0,008 & 0,023 & 0,026 & 0,034 \\
\hline $\begin{array}{ll}\text { b. } & \text { Tanaman } \\
\text { perkebunan } \\
\text { c. Peternakan dan }\end{array}$ & 0,043 & 0,046 & 0,047 & 0,050 & 0,052 \\
\hline hasil-hasilnya & $-0,010$ & $-0,009$ & $-0,009$ & $-0,008$ & $-0,009$ \\
\hline d. Kehutanan & 0,014 & 0,015 & 0,013 & 0,012 & 0,013 \\
\hline e. Perikanan & $-0,013$ & $-0,013$ & $-0,013$ & $-0,014$ & $-0,016$ \\
\hline
\end{tabular}

Analisis koefisien spesialisasi ( $\beta$ ) digunakan untuk menunjukkan apakah suatu wilayah mengkhususkan diri terhadap suatu jenis aktivitas ekonomi tertentu (spesialisasi) dengan cara membandingkan aktivitas sektor usaha di wilayah yang diteliti dengan wilayah yang lebih luas. Nilai koefisien $\beta$ yang lebih besar atau sama dengan 1 mengindikasikan bahwa terdapat spesialisasi dalam aktivitas sektor usaha pada wilayah yang diamati.

Hasil analisis koefisien $\beta$ menunjukkan bahwa sektor pertanian Kabupaten Poso tidak mengkhususkan diri terhadap suatu aktivitas produksi komoditas tertentu. Terlihat bahwa nilai koefisien $\beta$ yang diperoleh lebih kecil daripada 1 pada semua sub sektor yang diteliti.

Bila dihubungkan dengan nilai LQ yang memperlihatkan adanya sub sektor basis yang dapat mendukung pembangunan ekonomi karena memiliki karakteristik ekspor seperti sub sektor tanaman bahan makanan, perkebunan, dan kehutanan, maka hasil analisis koefisien $\beta$ yang diperoleh memperlihatkan bahwa aktivitas pada sub sektor basis baru dapat memenuhi kebutuhan wilayah Kabupaten Poso dan belum diarahkan untuk pemenuhan kebutuhan ekspor.

Pemerintah daerah perlu mencermati adanya sub-sub sektor pertanian yang memiliki peluang ekspor dengan melakukan spesialisasi. Spesialisasi yang dilakukan terhadap aktivitas-aktivitas produksi komoditas tertentu akan menghasilkan produk-produk yang memiliki keunggulan komparatif yang dapat memberikan kontribusi pada perekonomian daerah.

Hasil perhitungan nilai BSR dan REM dapat dilihat pada Tabel 7 sebagai berikut.

Tabel 7. Nilai BSR dan REM Sektor Pertanian di Kabupaten Poso Tahun 2009 - 2013

(Table 7. BSR and REM Values of Agriculture Sector in Poso Regency Year 2009-2013)

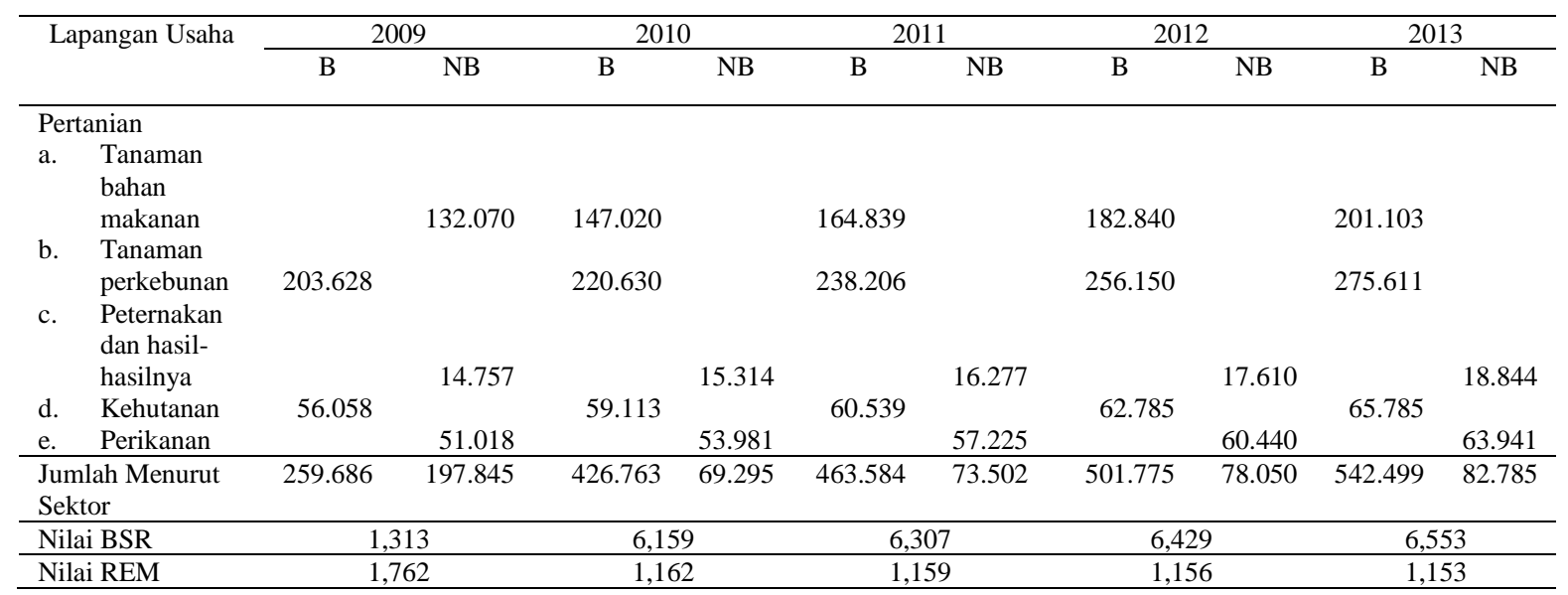


Analisis Basic Service Ratio (BSR) merupakan indikator untuk mengetahui sejauh mana hubungan dan pengaruh antara sektor basis dan non basis pada suatu wilayah. Semakin besar nilai BSR berarti semakin besar pendapatan dan jumlah tenaga kerja yang diperoleh sektor basis sehingga semakin besar pula peluang pengembangan ekonomi di wilayah yang bersangkutan.

Hasil analisis BSR untuk Kabupaten Poso menunjukkan bahwa sub-sub sektor basis dari sektor pertanian menghasilkan pendapatan yang cukup besar bagi masyarakat dan menyerap lebih banyak tenaga kerja. Hal ini tampak dari nilai BSR tahun 2009 s/d 2013 yang lebih besar dari 1.

Karena pentingnya peranan sub-sub sektor basis tersebut, maka pemerintah daerah perlu memberikan perhatian pada pengembangan sub-sub sektor yang dimaksud dengan dukungan sarana dan fasilitas yang diperlukan sehingga dapat mendorong sub-sub sektor tersebut memberikan kontribusi yang semakin besar pada kemajuann pembangunan ekonomi daerah.

Analisis Regional Employment Multiplier (REM) merupakan kelanjutan dari analisis BSR yang memperlihatkan sejauh mana pertumbuhan dan perkembangan sektor basis berpengaruh terhadap pertumbuhan dan perkembangan sektor non basis. Semakin besar nilai REM berarti semakin besar pengaruh sektor basis terhadap perkembangan sektor non basis dalam suatu wilayah.

Hasil analisis menunjukkan bahwa nilai REM yang diperoleh dari tahun 2009 s/d 2013 lebih besar daripada 1. Artinya apabila sektor basis mengalami peningkatan sebesar 1 satuan maka sektor non basis akan mengalami peningkatan sebesar lebih dari 1 satuan. Hal ini merupakan indikator bahwa keberadaan sub-sub sektor basis dari sektor pertanian di Kabupaten Poso merupakan penunjang bagi perkembangan sub-sub sektor non basis, sebab keberhasilan pembangunan sub-sub sektor basis akan memberikan dampak positif pada sub-sub sektor non basis berupa peningkatan pendapatan daerah dan semakin besarnya lapangan kerja yang dapat disediakan oleh sub-sub sektor non basis tersebut.

\section{KESIMPULAN DAN SARAN}

\section{Kesimpulan}

Kontribusi sektor pertanian terhadap PDRB Kabupaten Poso dari tahun 2009 hingga 2013 ialah rata-rata sebesar 44,07 \% per tahun, mengindikasikan bahwa perekonomian Kabupaten Poso bercorak agraris.

Sektor pertanian merupakan sektor basis bagi perekonomian Kabupaten Poso dengan sub-sub sektor berupa tanaman bahan makanan, perkebunan, dan kehutanan merupakan sub sektor basis. Hanya saja sub-sub sektor yang dimaksud belum terkonsentrasi pada suatu wilayah tertentu dan belum memiliki spesialisasi pada satu atau beberapa komoditas tertentu.

Sub-sub sektor basis dari sektor pertanian berkontribusi sebagai sumber pendapatan dan lapangan kerja bagi masyarakat. Pengembangan sub-sub sektor basis penting dilakukan karena dapat mendorong peningkatan aktivitas pada sub-sub sektor non basis.

\section{Saran}

Selain menggunakan data PDRB, perhitungan kontribusi dan penentuan basis tidaknya suatu sektor terhadap perekonomian disarankan untuk menggunakan pula data mikro berupa pendapatan petani pada lingkup wilayah tertentu dan dibandingkan dengan pendapatan petani pada tingkatan wilayah yang lebih tinggi.

\section{DAFTAR PUSTAKA}

1. Adisasmita, R. 2008. Pengembangan Wilayah : Konsep dan Teori. Penerbit Graha Ilmu. Yogyakarta. 
2. Azis, I.J. 1994. Ilmu Ekonomi Regional dan Beberapa Aplikasinya di Indonesia. Fakultas Ekonomi Universitas Indonesia. Jakarta.

3. BPS Poso. 2014. Produk Domestik Regional Bruto Kabupaten Poso Menurut Lapangan Usaha Tahun 2009 - 2013. Badan Pusat Statistik Kabupaten Poso. Poso.

4. BPS Sulteng. 2014. Produk Domestik Regional Bruto Provinsi Sulawesi Tengah Menurut Lapangan Usaha Tahun 2009 - 2013. Badan Pusat Statistik Provinsi Sulawesi Tengah. Palu.

5. Glasson, J. 1997. Pengantar Perencanaan Regional. Fakultas Ekonomi Universitas Indonesia. Jakarta.

6. Syafruddin, A.N. Kairupan, A. Negara, dan J. Limbongan. Penataan Sistem Pertanian dan Penetapan Komoditas Unggulan Berdasarkan Zona Agroekologi di Sulawesi Tengah. Jurnal Litbang Pertanian.

7. Tarigan, R. 2005. Ekonomi Regional : Teori dan Aplikasi. Bumi Aksara. Jakarta. 